\title{
THE HISTOPATHOLOGY OF CUTANEOUS LEISHMANIASIS DUE TO Leishmania (Leishmania) mexicana IN THE YUCATAN PENINSULA, MEXICO
}

\begin{abstract}
SUMMARY
Localized Cutaneous Leishmaniasis (LCL) known as "chiclero's ulcer" in southeast Mexico, was described by SEIDELIN in 1912. Since then the sylvatic region of the Yucatan peninsula has been documented as an endemic focus of LCL. This study of 73 biopsies from parasitological confirmed lesions of LCL cases of Leishmania (Leishmania) mexicana infection was undertaken: 1) to examine host response at tissue level; and 2) to relate manifestations of this response to some characteristics of clinical presentation. Based on Magalhães' classification we found that the most common pattern in our LCL cases caused by $L$. $(L$.) mexicana was predominantly characterized by the presence of unorganized granuloma without necrosis, (43.8\%). Another important finding to be highlighted is the fact that in 50/73 (68.5\%) parasite identification was positive. There was direct relation between the size of the lesion and time of evolution $\left(r_{s}=0.3079, p=0.03\right)$, and inverse correlation between size of the lesion and abundance of amastigotes $\left(r_{s}=-0.2467, p=0.03\right)$. In view of the complexity of clinical and histopathological findings, cell-mediated immune response of the disease related to clinical and histopathological features, as so genetic background should be studied.
\end{abstract}

KEYWORDS: Cutaneous Leishmaniasis; Histopathology; Leishmania (Leishmania) mexicana.

\section{INTRODUCTION}

Localized Cutaneous Leishmaniasis (LCL) known as "chiclero's ulcer" in southeast Mexico, was accurately described by SEIDELIN in $1912^{22}$. Since then the sylvatic region of the Yucatan peninsula has been documented as an endemic focus of $\mathrm{LCL}^{2,5,6,23}$. Leishmania (Leishmania) mexicana Biagi, 1953, emend. Garnham, 1962, is the main agent causing LCL in this focus ${ }^{9,10}$. Two species of wild rodents Ototylomys phyllotys and Peromyscus yucatanicus, have been found naturally infected by $L$. (L.) mexicana and fit all criteria to be incriminated as primary reservoirs ${ }^{11,25}$. Lutzomyia olmeca olmeca and $L u$. cruciata have been incriminated as potential vectors of $L$. $(L$.) mexicana ${ }^{17,18}$. L. (L.) mexicana in the endemic area of LCL in the State of Campeche, Yucatan peninsula, Mexico, presents a seasonal transmission restricted to the months of November to $\mathrm{March}^{4}$. The clinical picture is characterized by a predominantly single, painless, ulcerated lesion, without lymphangitis adenopathy, as so mucosal involvement, and when located on the ear (the most common presentation) tends to become chronic, causing destruction of the pinna and disfigurement ${ }^{3,7,14,27}$. One hundred and five patients treated with meglumine antimoniate at a daily dose of one ampoule per day (425 $\mathrm{mg}$ of $\mathrm{Sb}^{+}$) healed after a mean of 25 days (range $=5-60$ days) ${ }^{26}$.

Although the epidemiology, clinical picture and response to treatment with meglumine antimoniate of LCL caused by $L$. (L.) mexicana have been adequately described in southeast Mexico, the histopathology has not been characterized. MARROQUIN \& BIAGI analyzed 19 biopsies from 18 patients with "chiclero's ulcer" but 13 of them had more than two years of evolution, thus the parasite visualization was possible in only $2 / 13(15.38 \%)$ and the species of Leishmania was not identified. They reported a cellular infiltrate of plasma and epithelioid cells in all the biopsies ${ }^{16}$.

The present study of 73 biopsies from parasitological confirmed lesions of LCL cases of $L$. (L.) mexicana infection was undertaken: 1) to examine host response at tissue level; and 2) to relate manifestations of this response to some characteristics of clinical presentation.

\section{MATERIALS AND METHODS}

Patient population: Patients from the Yucatan peninsula, Mexico, evaluated in a long-term clinical-epidemiological study to define dynamics of transmission of $L$. (L.) mexicana in that focus, with a suggestive clinical picture of LCL, and who sought treatment between January 1990 and December 1995 were included. This study was reviewed and approved by the Ethical Committee of the Universidad Autonoma de Yucatan, in agreement with international ethical guidelines for biomedical research involving human subjects (Ley General de Salud, Mexico). A written informed consent to participate was obtained from each patient.

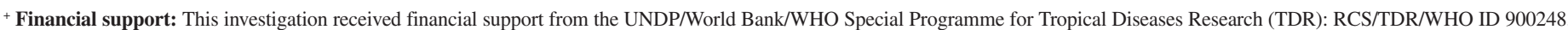
(1) Laboratorio de Inmunología, Centro de Investigaciones Regionales "Dr. Hideyo Noguchi”, Universidad Autónoma de Yucatán, Mérida, Yucatán, México.

(2) Facultad de Matemáticas, Universidad Autónoma de Yucatán, Mérida, Yucatán, México.

(3) Departamento de Inmunología, Escuela Nacional de Ciencias Biológicas, Instituto Politécnico, Nacional, México, DF.

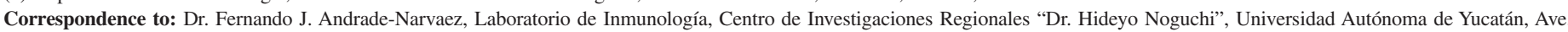
Itzáes No. 490x59, CP 97000, Mérida, Yucatán, México. Fax: 52999 923-6120. e-mail: anarvaez@tunku.uady.mx
} 


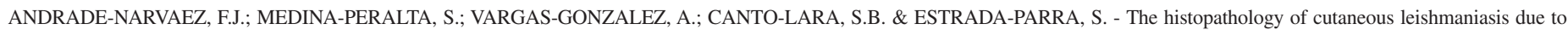
Leishmania (Leishmania) mexicana in the Yucatan peninsula, Mexico. Rev. Inst. Med. trop. S. Paulo, 47(4):191-194 , 2005.

Four hundred and forty five individuals with skin lesions suggestive of Leishmania infection were studied. In all instances, complete clinical histories were taken, and careful questioning was performed. In order to be related to host response at tissue level the following clinical features were recorded: age; sex; time of evolution (duration of disease prior to diagnosis); number, location, and size (diameter in $\mathrm{cm}^{2}$ ) of lesions; and response to treatment (number of ampoules of meglumine antimoniate administrated until healing). Criteria to be included in this study comprehended a confirmed diagnosis of LCL based on visualization of the parasite by smear, biopsy, and isolation-culture ${ }^{12}$.

Characterization of parasites: Parasites isolated by needle aspirates from the edge of the lesion were inoculated into a tube of Senekjie's modified medium and kept at $22{ }^{\circ} \mathrm{C}$. After initial growth in culture tubes, the parasites were mass cultivated for isoenzyme electrophoresis and analyses with monoclonal antibodies as described previously ${ }^{9,10}$.

Histopathology: Skin biopsies were taken from the edge of the lesion (avoiding ulcerated and heavily crusted parts) with a 4-mm disposable punch and $2 \%$ xylocaine as an anesthetic. The material was fixed in neutral formalin, routinely processed and embedded in paraffin. Sections were stained with hematoxylin and eosin. Histopathological findings were grouped in patterns according to a classification proposed by MAGALHÃES et al. in a study performed to characterize histopathology of CL and MCL caused by Leishmania (Viannia) braziliensis ${ }^{15}$. In this study a total of five histopathological patterns were identified: type I) exudative-cellular reaction due to infiltration of histiocytes, lymphocytes, and plasma cells, without granuloma; type II) exudative-necrotic reaction, characterized by cellular infiltration, and necrosis and no granulomatous response; type III) exudative and necrotic-granulomatous reaction (unorganized granuloma) corresponding to pattern described as chronic granulomatous inflammation with necrosis; type IV) exudative granulomatous reaction (unorganized granuloma) without necrosis characterized by the presence of an unorganized granulomatous reaction; type $\mathrm{V}$ ) exudative tuberculoid reaction in which a typical tuberculoid granuloma (organized) is formed.

Histopathological features recorded to be analyzed comprehended presence or absence of: necrosis, unorganized or organized granuloma, eosinophils, giant cells and polymorphonuclears; lymphocytes, plasma cells, macrophages (histiocytes) and amastigotes (parasite index) were estimated through an arbitrary semiquantitative procedure (from scarce to abundant).

Statistical analysis: Spearman correlation coefficient was used in bivariate analysis of age: time of evolution, age: number of ampoules, age: size of the lesion, age: parasite index, age: presence of granuloma; time of evolution: presence of granuloma, time of evolution: parasite index, time of evolution: necrosis, time of evolution: number of ampoules; number of ampoules: granuloma, number of ampoules: parasite index; size of the lesion: time of evolution, size of the lesion: granuloma, size of the lesion: parasite index; eosinophils: polymorphonuclears; lymphocytes: plasma cells; lymphocytes: granuloma; macrophages: lymphocytes; macrophages: granuloma; macrophages: parasite index; giant cells: number of ampoules.

The test of U de Mann-Whitney was used to determine differences between men and women regarding: time of evolution, number of ampoules and size of the lesion. Also to determine differences between (positive or negative) levels of giant cells related to time of evolution and number of ampoules, and to determine differences among levels of necrosis related to time of evolution.

Kruskal-Wallis test was used to determine differences in time of evolution regarding: a) presence of granuloma, b) levels of parasite index, c) location of the lesion; as so number of ampoules administered regarding: a) time of evolution and b) parasite index. Finally was used to determine differences in size of the lesion related to: a) location of the lesion, b) time of evolution, c) presence of granuloma and d) parasite index.

ANOVA was employed to compare the number of ampoules related to the presence and type of granuloma.

\section{RESULTS}

Clinical picture: Between January 1990 and December 1995, parasite demonstration by smear, biopsy, and/or isolation-culture was positive in 445 patients with suggestive LCL. L. (L.) mexicana was successfully isolated, cultured, and identified by isoenzyme characterization and/or monoclonal antibodies in $136(30.5 \%)$ as reported previously. From these cases of LCL caused by $L$. (L.) mexicana, biopsies were taken in a total of $73(53.67 \%)$. Males (68/ $73,93.15 \%$ ) were mainly affected between seven to 69 years old. The most common lesions were single $(82.19 \%)$ and located on the ear (38. 35\%). Clinical features were not significantly different from those reported previously regarding time of evolution, number of lesions, and location, considering that the sample is from the same source ${ }^{3}$.

Histopathology: The histopathological picture varied so widely that it was difficult to accommodate findings in a meaningful pattern. Based on Magalhães' classification, we found the following distribution according to histopathological patterns: type I, 8/73 (10.9\%); type II, 7/73 (9.5\%); type II; type III, 21/73 (28.7\%); type IV, 32/73 (43\%); and type $\mathrm{V}, 5 / 73(6.8 \%)$. Parasite identification was positive in 50/73 $(68.5 \%)$.

Correlation between clinical, histopathological and clinicalhistopathological features: There was direct relation between the size of the lesion and time of evolution $\left(r_{s}=0.3079, p=0.03\right)$. Regarding histopathological features abundance of lymphocytes was directly related to the presence of granuloma $\left(r_{s}=0.3192, p=0.006\right)$, and number of macrophages with abundance of amastigotes $\left(r_{s}=0.7815, p=0.000\right)$. It was observed that the number of lymphocytes was inversely related to the number of plasma cells $\left(r_{s}=-0.9675, p=0.000\right)$, as so the number of macrophages and lymphocytes $\left(r_{s}=-0.2755, p=0.01\right)$, and the number of macrophages and presence of granuloma $\left(r_{s}=-0.3790, p=\right.$ 0.001). Finally, with reference to clinical-histopathological features an inverse correlation between size of the lesion and abundance of amastigotes $\left(r_{s}=-0.2467, p=0.03\right)$ was observed.

\section{DISCUSSION}

The present study is the first published record of histopathological features of LCL caused by $L$. (L.) mexicana in an endemic area of the southeast of Mexico and correlation study amongst the variables of 


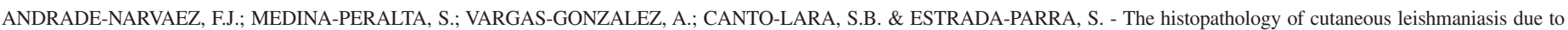
Leishmania (Leishmania) mexicana in the Yucatan peninsula, Mexico. Rev. Inst. Med. trop. S. Paulo, 47(4):191-194 , 2005.

clinical history data as well as variables of histopathology data to assess the extent to which the set of clinical variables is related to the set of histopathology variables.

The essential feature of CL pathology is the colonization by amastigotes of cells of the mononuclear phagocytic system and the resulting granulomatous inflammatory response. A granuloma is defined as a compact collection of mature mononuclear phagocytes, not necessarily accompanied by accessory features such as necrosis. Conceptually granuloma evolves in three stages: 1) the development of an infiltrate of young mononuclear phagocytes; 2) the maturation and aggregation of these cells into an unorganized granuloma; and 3) the potential maturation of these cells into an epithelioid or organized granuloma ${ }^{1}$.

RIDLEY pointed out the usefulness of describing the histological spectrum of CL to throw some light on the immunological mechanisms involved and to produce a classification related to prognosis ${ }^{19}$. Moreover, RIDLEY et al. emphasized the importance of studying one focus in which there is a well-defined clinical form and one identified Leishmania species, to reach a good characterization of the predominant histological pattern ${ }^{20}$.

Although the histopathological presentation of CL shows a great variability, a predominant pattern characterized by the presence of unorganized granuloma without necrosis $(43.8 \%)$ was observed and it could be related with the species of Leishmania as it is supported by data shown. However, relation between specific geographical differences and the histopathology of CL is limited, because of hostparasite interactions in space as well as time complexity. Moreover, another factor that complicates this approach is the fact that the pattern can be distinct within the same lesion depending on time of evolution ${ }^{8}$. It would be very useful to study associations among clinical, histological and immunological variables in order to identify possible markers of prognosis $^{24}$.

There is only one study regarding the correlation between histopathology, immune response, clinical presentation, and evolution of L. (V.) braziliensis infection ${ }^{13}$. Skin biopsies from 221 parasitologically confirmed cases of CL caused by L. (V.) braziliensis were evaluated. They found that the presence of amastigotes was inversely related to the duration of the lesion $(p<0.001)$ and the presence of eosinophils $(\mathrm{p}<0.01)$, whereas the presence of adenopathy $(\mathrm{p}=0.001)$, necrosis $(\mathrm{p}=0.02)$ and histiocytes $(\mathrm{p}=0.001)$ were directly associated with the presence of amastigotes. Moreover, the presence of epithelioid and giant cells $(\mathrm{p}=0.03)$ was associated with fewer drugs being required to achieve healing.

In the present study regarding correlation of clinical features it looks that age and sex do not play an important role in the outcome and response to treatment, although in a previous study we have reported that the only association that approached statistical significance was between number of ampoules required and age in patients lesser than 15 years old ${ }^{3}$.

With reference to clinical-histopathological correlations, we found the following results that correspond to the $L$. (V.) braziliensis ${ }^{13}$. Data related to abundance of amastigotes and size of the lesion $(\mathrm{p}=0.03)$, as so time of evolution and size of the lesion $(\mathrm{p}=0.03)$, could be interpreted as equivalent to the finding of number of amastigotes inversely related to the duration of disease; and the number of macrophages (histiocytes) were directly associated to the number of amastigotes $(\mathrm{p}=0.000)$.

There were however differences between both correlation studies caused by $L$. (L.) mexicana or $L$. (V.) braziliensis. One of the findings reported and discussed in the $L$. (V.) braziliensis study was the fact that presence of amastigotes was inversely related to the presence of eosinophils that we could not find in the present study. Another result of importance for prognosis was the association of giant cells with fewer drugs being required for healing that we could not find also.

It is generally accepted that CL is polymorphic in its clinical presentation and evolution, which may be due to variability in parasite virulence or in the host genetic background and immune response ${ }^{3,24,27}$. $L$. (V) braziliensis is considered more pathogenic and virulent than $L$. (L.) mexicana. If the histopathological differences correlate with the pathogenesis and virulence of Leishmania spp. and/or host genetic background and immune response remains to be solved.

\section{RESUMEN}

\section{Histopatologia de la leishmaniasis cutánea causada por Leishmania (Leishmania) mexicana en la Península de Yucatán, México}

La Leishmaniosis Cutánea Localizada (LCL) mejor conocida como "úlcera del chiclero" en el sureste de México fue descrita por SEIDELIN en 1912. Desde entonces la región selvática de la península de Yucatán ha sido identificada como un área endémica de LCL. En el presente estudio se analizaron 73 biopsias de lesiones de casos de LCL causados por Leishmania (Leishmania) mexicana con el fin de: 1) examinar la respuesta a nivel tisular; y 2) relacionar las manifestaciones de esta respuesta con ciertas características de la presentación clínica. Con base en la clasificación histopatológica de Magalhães el patrón histopatológico más frecuente se caracterizó por la presencia de granuloma desorganizado y ausencia de necrosis $(43.83 \%)$. Otro hallazgo importante a señalar fue la presencia de parásito en 50/73 $(68.5 \%)$ de las biopsias estudiadas. Respecto a las posibles relaciones significativas hubo una relación directa entre el tamaño de la lesión y el tiempo de evolución $\left(\mathrm{r}_{\mathrm{s}}=0.3079, \mathrm{p}=0.03\right)$; una correlación inversa entre el tamaño de la lesión y la abundancia de promastigostes $\left(\mathrm{r}_{\mathrm{s}}=\right.$ -0.2467, $\mathrm{p}=0.03$ ). Con base en la complejidad de los hallazgos clínicos e histopatológicos, consideramos necesario estudiar la respuesta inmune mediada por células relacionada con los cambios histopatológicos, así como el papel de los factores genéticos.

\section{ACKNOWLEDGEMENTS}

To the personnel of the "Programa Solidaridad" of the "Instituto Mexicano del Seguro Social" (IMSS-Solidaridad) and to the "Secretaría de Salud", from the State of Campeche, for their collaboration in case detection and notification; to Nicole R Van Wynsberghe MSc for her careful editing of the manuscript. 


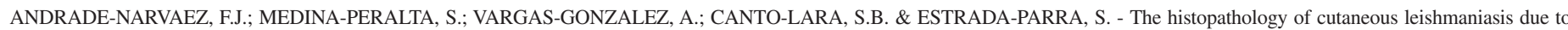
Leishmania (Leishmania) mexicana in the Yucatan peninsula, Mexico. Rev. Inst. Med. trop. S. Paulo, 47(4):191-194 , 2005.

\section{REFERENCES}

1. ADAMS, D.O. - The granulomatous inflammatory response. A review. Amer. J. Path., 84: 164-191, 1976

2. ANDRADE-NARVAEZ, F.J.; SIMMONDS-DIAZ, E.B.; AGUILAR-RICO, S. et al. Incidence of localized cutaneous leishmaniasis (Chiclero's ulcer) in Mexico. Trans. roy. Soc. trop. Med. Hyg., 84: 219-220, 1990.

3. ANDRADE-NARVAEZ, F.J.; VARGAS-GONZALEZ, A.; CANTO-LARA, S.B. \& DAMIAN-CENTENO, A.G. - Clinical picture of cutaneous leishmaniasis due to Leishmania (Leishmania) mexicana in the Yucatan peninsula, Mexico. Mem. Inst. Oswaldo Cruz, 96: 163-167, 2001.

4. ANDRADE-NARVAEZ, F.J.; CANTO-LARA, S.B.; VAN WYNSBERGHE, N.R. et al. Seasonal transmission of Leishmania (Leishmania) mexicana in the State of Campeche, Yucatan peninsula, Mexico. Mem. Inst. Oswaldo Cruz, 98: 995-998, 2003 .

5. BELTRÁN, F. \& BUSTAMANTE, M.E. - Datos epidemiológicos acerca de la "úlcera de los chicleros" (leishmaniasis americana) en México. Rev. Inst. Salubr. Enferm. trop. (Méx.), 3: 1-28, 1942.

6. BIAGI, F.; MARROQUIN, F. \& GONZALEZ, A. - Distribución geográfica de la leishmaniasis en Mexico. Medicina (Méx.), 37: 444-446, 1957.

7. BIAGI, F. - Síntesis de 70 historias clínicas de leishmaniasis tegumentaria en México (úlcera de los chicleros). Medicina (Méx.), 33: 385-396, 1953.

8. BITTENCOURT, A.L. \& BARRAL, A. - Evaluation of the histopathological classifications of American cutaneous and mucocutaneous leishmaniasis. Mem. Inst. Oswaldo Cruz, 86: 51-56, 1991.

9. CANTO-LARA, S.B.; CÁRDENAS-MARUFFO, M.F.; VARGAS-GONZALEZ, A. \& ANDRADE-NARVAEZ, F.J. - Isoenzyme characterization of Leishmania isolated from human cases with localized cutaneous leishmaniasis from the State of Campeche, Yucatan peninsula, Mexico. Amer. J. trop. Med. Hyg., 58: 444-447, 1998.

10. CANTO-LARA, S.B.; VAN WYNSBERGHE, N.R.; VARGAS-GONZALEZ, A.; OJEDAFARFAN, F.F. \& ANDRADE-NARVAEZ, F.J. - Use of monoclonal antibodies for the identification of Leishmania spp. isolated from humans and rodents in the State of Campeche, Mexico. Mem. Inst. Oswaldo Cruz, 94: 305-309, 1999.

11. CHABLE-SANTOS, J.B.; VAN WYNSBERGHE, N.R.; CANTO-LARA, S.B. \& ANDRADE-NARVAEZ, F.J. - Isolation of Leishmania (L.) mexicana from wild rodents and their possible role in the transmission of localized cutaneous leishmaniasis in the State of Campeche, Mexico. Amer. J. trop. Med. Hyg., 53: 141-145, 1995.

12. GARCIA-MISS, M.R.; ANDRADE-NARVAEZ, F.J.; ESQUIVEL-VIÑAS, R.E. et al. Localized cutaneous leishmaniasis (chiclero's ulcer) in Mexico: sensitivity and specificity of ELISA for IgG antibodies to Leishmania mexicana mexicana. Trans. roy. Soc. trop. Med. Hyg., 84: 356-358, 1990.

13. GUTIÉRREZ, Y.; SAliNAS, G.H.; PALMA, G. et al. - Correlation between histopathology, immune response, clinical presentation, and evolution in Leishmania braziliensis infection. Amer. J. trop. Med. Hyg., 45: 281-289, 1991.

14. LAINSON, R. \& STRANGSWAYS-DIXON, J. - Leishmania mexicana: the epidemiology of dermal leishmaniasis in British Honduras. Trans. roy. Soc. trop. Med. Hyg., 57: 242-265, 1963
15. MAGAlHÃES, A.V.; MORAES, M.A.P.; RAICK A.N. et al. - Histopatologia da leishmaniose tegumentar por Leishmania braziliensis braziliensis. 1. Padrões histopatológicos e estudo evolutivo das lesões. Rev. Inst. Med. trop. S. Paulo, 28: 253-262, 1986.

16. MARROQUÍN, F. \& BIAGI, F. - Estudio de 19 biopsias de leishmaniasis tegumentaria en México. Rev. lat.-amer. Anat. pat., 1: 145-150, 1957.

17. REBOLLAR-TELLEZ, E.A.; REYES-VILLANUEVA, F.; FERNANDEZ-SALAS, I. \& ANDRADE-NARVAEZ, F.J. - Population dynamics and biting rhythm of the anthropophilic sandfly Lutzomyia cruciata (Diptera: Psychodidae) in southeast, Mexico. Rev. Inst. Med. trop. S. Paulo, 38: 29-33, 1996.

18. REBOLLAR-TELLEZ, E.A.; RAMIREZ-FRAIRE, A. \& ANDRADE-NARVAEZ, F.J. A two years study on vectors of cutaneous leishmaniasis. Evidence for sylvatic transmission cycle in the State of Campeche, Mexico. Mem. Inst. Oswaldo Cruz, 91: 555-560, 1996.

19. RIDLEY, D.S. - The pathogenesis of cutaneous leishmaniasis. Trans. roy. Soc. trop. Med. Hyg., 73: 150-160, 1979.

20. RIDLEY, D.S. - A histological classification of cutaneous leishmaniasis and its geographical expression. Trans. roy. Soc. trop. Med. Hyg., 74: 515-521, 1980.

21. RIDLEY, D.S.; MARSDEN, P.D.; CUBA, C.C. \& BARRETO, A.C. - A histological classification of mucocutaneous leishmaniasis in Brazil and its clinical evaluation. Trans. roy. Soc. trop. Med. Hyg, 74: 508-514, 1980

22. SEIDELIN, H. - Leishmaniasis and babesiasis in Yucatan. Ann. trop. Med. Parasit., 6: 295-299, 1912.

23. SHATTUCK, G.C. - Leishmania, Trachoma and Foliculosis. In: SHATTUCK G.C., ed The Peninsula of Yucatan. Medical, biological, meteorological and sociological studies. Washington, Carnegie Institution, 1933. p. 318-327.

24. SILVEIRA, F.T.; LAINSON, R. \& CORBETT, C.E.P. - Clinical and immunopathological spectrum of American cutaneous leishmaniasis with special reference to the disease in Amazonian Brazil. A review. Mem. Inst. Oswaldo Cruz, 99: 239-251, 2004.

25. VAN WYNSBERGHE, N.R.; CANTO-LARA, S.B.; DAMIAN-CENTENO, A.G.; ITZÁORTIZ, M.F. \& ANDRADE-NARVAEZ, F.J. - Retention of Leishmania (Leishmania) mexicana in naturally infected rodents from the State of Campeche, Mexico. Mem. Inst. Oswaldo Cruz, 95: 595-600, 2000.

26. VARGAS-GONZALEZ, A.; CANTO-LARA, S.B.; DAMIÁN-CENTENO, A.G. \& ANDRADE-NARVAEZ, F.J. - Response of cutaneous leishmaniasis ("chiclero's ulcer") to treatment with meglumine antimoniate in Southeast Mexico. Amer. J. trop. Med. Hyg., 61: 960-963, 1999.

27. WALTON, B.C. - American cutaneous and mucocutaneous leishmaniasis. In: PETERS W. \& KILLICK-KENDRICK, R., ed. The Leishmaniasis in Biology and Medicine. Clinical aspects and control. London, Academic Press, 1987. v. 2.

Received: 11 January 2005

Accepted: 31 May 2005 